\title{
Drying kinetics of araticum (Annona crassiflora) epicarp
}

\author{
Iva Manoela Rocha ATAIDES ${ }^{1}$, Daniel Emanuel Cabral de OLIVEIRA², Weder Nunes FERREIRA JUNIOR ${ }^{1}$, \\ Osvaldo RESENDE ${ }^{1}$, Wellytton Darci QUEQUETO ${ }^{1 *}$ (1)
}

\begin{abstract}
Araticum (Annona crassiflora) fruits have relevant characteristics for industrialization, a characteristic aroma and a slightly acidic flavor, with relevant amounts of vitamins A, C, B1 and B2. The objective of this study was to fit different mathematical models to the experimental data, evaluate the effective diffusion coefficient and determine the activation energy for the araticum epicarp subjected to different drying conditions. The epicarps of araticum fruits were dried at temperatures of 40, 50, 60 and $70{ }^{\circ} \mathrm{C}$. Midilli, Logarithmic and Two Terms models can be used to represent the drying of araticum epicarp, and the Two Terms model was selected according to the Akaike Information Criterion (AIC) and Schwarz's Bayesian Information Criterion (BIC). The linear model satisfactorily represented the effective diffusion coefficient as a function of drying temperature. In the evaluation of enthalpy, entropy and Gibbs free energy, both enthalpy and entropy tend to decrease when temperature increases. The higher the temperature used for drying of araticum epicarp, the lower the value of diffusivity, i.e., the lower the resistance to water removal.
\end{abstract}

Keywords: mathematical modeling; epicarp; two terms; AIC and BIC.

Practical Application: Contribute to estimate the drying process of the araticum epicarp in different conditions.

\section{Introduction}

Araticum (Annona crassiflora) fruits are very popular and appreciated in the Cerrado regions and in the interior of Brazil. Depending on the region, it is called 'pinha', 'ata,' 'marolo', 'condessa', 'bruto', 'cabeça-de-negro', among others. The name araticum derives from Tupi and means "stiff and hard tree, fruit of heaven, tasty, or soft fruit", and the fruit is covered by a thick brown peel and has in its interior a large amount of smooth and black seeds surrounded with a tasty pulp (Fachinello \& Nachtigal, 2010).

An alternative for fruit conservation is drying, a process widely used to remove the water present in food in order to preserve its nutritional value as much as possible, inhibiting microbial development (Machado, 2011). However, in this process there is a volumetric concentration, known as "shrinkage", defined as deformation in the structure, as well as in the shape and size of the sample, besides simultaneously involving the complex phenomena of heat and mass transfer (Aprajeeta et al., 2015). Drying processes are influenced by moisture content loss, mass reduction and unfavorable conditions for microbial growth.

According Costa et al. (2015), it is extremely important to use mathematical models and parameters that best fit to the loss of water from the product can be adopted, justified by theoretical information about drying.

Based on how important it is to study the drying process of plant products, the objective was to fit different mathematical models to the experimental data, using some criteria for selecting the best model, and to evaluate the effective diffusion coefficient and activation energy for araticum epicarp at different drying temperatures.

\section{Material and methods}

\subsection{Obtaining of araticum fruit}

Araticum (Annona crassiflora) fruits were obtained from araticum trees on a farm located in the rural area of the municipality of Montividiu, state of Goiás, Brazil, from the 2017 season of the Midwest region of Goiás. They were harvested directly from the plant and separated according to the degree of maturity, in sacks, and sent to the Laboratory of Post-Harvest of Plant Products of the Federal Institute of Goiás - Campus Rio Verde.

As soon as the fruits reached an adequate degree of maturity, the peduncles were removed, washed in running water, sanitized by immersion in $150 \mathrm{ppm} \mathrm{L}^{-1}$ sodium hypochlorite for ten minutes, and then rinsed to remove residual chlorine. The fruits were subjected to pulping for separating the epicarp, packed in polyethylene bags and frozen $\left(-20^{\circ} \mathrm{C}\right)$ for conservation until the time of drying.

\subsection{Drying study}

Drying of the epicarp was performed at temperatures of 40 , 50,60 and $70{ }^{\circ} \mathrm{C}$, with relative internal moisture of $34.0,18.1$, 11.4 and $7.0 \%$, respectively. 
For the determination of the drying curves and fits of the models, an initial average moisture content of 1.17 (dry basis, d.b.) and a final average moisture content of $0.05 \pm 0.03$ (d.b.) were established for the epicarp, respectively, and the moisture contents of the product were determined in an oven at $105 \pm 3{ }^{\circ} \mathrm{C}$, until reaching constant mass, in three replicates (Association of Official Analytical Chemists, 2012).

The epicarps (length: $53 \mathrm{~mm}$; width: $35 \mathrm{~mm}$ and thickness: $5 \mathrm{~mm}$ ), were homogeneously distributed and dried in trays without perforations (length: $250 \mathrm{~mm}$; width: $150 \mathrm{~mm}$ and layer thickness: $10 \mathrm{~mm}$ ), containing $200 \mathrm{~g}$ of product in a completely randomized design, in three replicates.

To obtain the equilibrium moisture content (Xe), three repetitions containing $10 \mathrm{~g}$ were maintained under the drying conditions indicated above $\left(40,50,60\right.$ and $\left.70{ }^{\circ} \mathrm{C}\right)$ and periodically weighed until the mass remained constant. Subsequently, equilibrium moisture contents of the product were determined in an oven at $105 \pm 3{ }^{\circ} \mathrm{C}$, until reaching constant mass, in three replicates (Association of Official Analytical Chemists, 2012).

\subsection{Mathematical modeling of drying}

The following expression was used to determine the moisture content ratios of the epicarp during drying:

$$
\mathrm{RX}=\frac{\mathrm{X}^{*}-\mathrm{X}_{\mathrm{e}}^{*}}{\mathrm{x}_{\mathrm{i}}^{*}-\mathrm{x}_{\mathrm{e}}^{*}}
$$

Where:

$\mathrm{RX}$ : moisture content ratio, dimensionless;

$\mathrm{X}^{*}$ : moisture content of the product (d.b.);

$\mathrm{X}_{\mathrm{i}}^{*}$ : initial moisture content of the product (d.b.);

$\mathrm{X}_{\mathrm{e}}^{*}$ : equilibrium moisture content of the product (d.b.);

To represent the drying process, the empirical mathematical models frequently used as described in the Table 1 were fitted.
The mathematical models were fitted to the experimental drying data by nonlinear regression analysis, following the Gauss-Newton method using R statistical software. The values reported in the literature for the modeling of other agricultural products were adopted as a criterion for the initial approximations of the coefficients of the models. The degree of fit for each drying temperature was determined considering the significance of the regression coefficients by the t-test, adopting 5\% significance level, the magnitude of the coefficient of determination $\left(\mathrm{R}^{2}\right)$, the values of the mean relative error $(\mathrm{P})$ and the mean estimated error (SE), the Chi-square test $\left(\chi^{2}\right)$ at $5 \%$ significance level and confidence interval of $95 \%$ ( $\mathrm{p}<0.05)$, according to Mohapatra \& Srinivasa Rao (2005).

$\mathrm{P}=\frac{100}{n} \sum \frac{|\mathrm{Y}-\hat{\mathrm{Y}}|}{\mathrm{Y}}$

$\mathrm{SE}=\sqrt{\frac{\sum(\mathrm{Y}-\hat{\mathrm{Y}})^{2}}{\mathrm{DF}}}$

$\chi^{2}=\frac{\sum(\mathrm{Y}-\hat{\mathrm{Y}})^{2}}{\mathrm{DF}}$

Where:

$\mathrm{P}$ - Mean relative error (\%);

$\mathrm{N}$ - number of experimental observations;

Y - value observed experimentally;

$\hat{Y}$ - value estimated by the model;

SE - Mean estimated error;

DF - Degrees of freedom of the model (number of observations minus the number of parameters of the model).

Table 1. Mathematical models used to predict the drying of araticum epicarp.

\begin{tabular}{|c|c|c|}
\hline Model designation & Model & \\
\hline$R X=1+a t+b t^{2}$ & Wang \& Sing & (2) \\
\hline $\mathrm{RX}=\mathrm{a} \cdot \exp (-\mathrm{k} \cdot \mathrm{t})+(1-\mathrm{a}) \exp \left(-\mathrm{k}_{1} \cdot \mathrm{t}\right)$ & Verma & (3) \\
\hline $\mathrm{RX}=\exp \left(\left(-\mathrm{a}-\left(\mathrm{a}^{2}+4 \cdot \mathrm{b} \cdot \mathrm{t}\right)^{0.5}\right) / 2 \cdot \mathrm{b}\right)$ & Thompson & (4) \\
\hline $\mathrm{RX}=\exp \left(-\mathrm{k} \cdot \mathrm{t}^{\mathrm{n}}\right)$ & Page & $(5)$ \\
\hline$R X=\exp (-k \cdot t)$ & Newton & (6) \\
\hline $\mathrm{RX}=\mathrm{a} \cdot \exp \left(-\mathrm{k} \cdot \mathrm{t}^{\mathrm{n}}\right)+\mathrm{b} \cdot \mathrm{t}$ & Midilli & (7) \\
\hline$R X=a \cdot \exp (-k \cdot t)+c$ & Logarithmic & $(8)$ \\
\hline$R X=a \cdot \exp (-k \cdot t)$ & Henderson \& Pabis & (9) \\
\hline$R X=a \cdot \exp (-k \cdot t)+(1-a) \exp (-k \cdot a \cdot t)$ & Two-Term Exponential & $(10)$ \\
\hline$R X=a \cdot \exp \left(-k_{0} \cdot t\right)+b \cdot \exp \left(-k_{1} \cdot t\right)$ & Two Terms & $(11)$ \\
\hline$R X=a \cdot \exp (-k \cdot t)+(1-a) \cdot \exp (-k \cdot b \cdot t)$ & Approximation of Diffusion & $(12)$ \\
\hline
\end{tabular}

$\mathrm{t}$ - drying time, h; k, ko, k1 - drying constants, h-1; a, b, c, n - coefficients of the models; RX - moisture content ratio, dimensionless 
To select a single model to describe the drying process of the araticum epicarp under each condition, the models that obtained the best fits were subjected to the Akaike Information Criterion (AIC) and the Schwarz's Bayesian Information Criterion (BIC). Lower values of AIC and BIC indicate better fit of the model, and $\mathrm{BIC}$ is the most rigorous criterion (Wolfinger, 1993). According to Gomes et al. (2018), these criteria can be additionally included for the selection of drying models. The information criteria were determined by Equations 16 and 17 .

$$
\begin{aligned}
& \mathrm{AIC}=-2 \log \mathrm{L}+2 \mathrm{p} \\
& \mathrm{BIC}=-2 \log \mathrm{L}+\mathrm{p} \ln (\mathrm{N}-\mathrm{r})
\end{aligned}
$$

Where:

$\mathrm{p}$ - number of parameters of the model;

$\mathrm{N}$ - total number of observations;

$r$ - rank of matrix X (incidence matrix of fixed effects);

L - maximum likelihood.

\subsection{Effective diffusion coefficient and activation energy}

The effective diffusion coefficient for the various drying conditions was determined according to the model based on the liquid diffusion theory, according to Fick's law, with the analytical solution for the geometric form of flat plate for the epicarps, with eight-term approximation (Equation 18):

$$
\mathrm{RX}=\frac{\mathrm{X}-\mathrm{X}_{\mathrm{e}}}{\mathrm{X}_{\mathrm{i}}-\mathrm{X}_{\mathrm{e}}}=\left(\frac{8}{\pi^{2}}\right) \sum_{n=0}^{\infty} \frac{1}{(2 n+1)^{2}} \exp \left[-\frac{(2 n+1)^{2} \cdot \pi \cdot \mathrm{D} \cdot \mathrm{t}}{4} \cdot\left(\frac{\mathrm{S}}{\mathrm{V}}\right)^{2}\right]
$$

Where:

RX - moisture content ratio of the product (dimensionless);

$\mathrm{N}$ - number of terms;

D - effective diffusion coefficient $\left(\mathrm{m}^{2} \mathrm{~s}^{-1}\right)$;

$\mathrm{S}$ - surface area of the epicarp, $\left(\mathrm{m}^{2}\right)$;

$\mathrm{V}$ - volume of the epicarp, $\left(\mathrm{m}^{3}\right)$.

The surface area of the epicarp were determined considering the measurements of length, width and thickness of the epicarp at the beginning of the drying process. The measurements were made in fifteen epicarp, using a digital pachymeter with a resolution of $0.01 \mathrm{~mm}$. With the average data of epicarp thickness and surface area, it was possible to calculate the volume, according to the following Equation 19:

$\mathrm{V}=\mathrm{S} \cdot \mathrm{e}$

Where,

e - epicarp thickness (m).

The relationship between the effective diffusion coefficient and the increase in drying air temperature was described using the Arrhenius Equation 20.
$\mathrm{D}=\mathrm{D}_{0} \exp \left(\frac{\mathrm{E}_{\mathrm{a}}}{\mathrm{R} \mathrm{T}_{\mathrm{abs}}}\right)$

Where,

D - effective diffusion coefficient $\left(\mathrm{m}^{2} \mathrm{~s}^{-1}\right)$;

$\mathrm{D}_{\mathrm{o}}$ - pre-exponential factor $\left(\mathrm{m}^{2} \mathrm{~s}^{-1}\right)$;

$\mathrm{E}_{\mathrm{a}}$ - activation energy $\left(\mathrm{kJ} \mathrm{mol}^{-1}\right)$;

$\mathrm{R}$ - universal constant of gases, $\left(8.134 \mathrm{~kJ} \mathrm{kmol}^{-1} \mathrm{~K}^{-1}\right)$; and

$\mathrm{T}_{\mathrm{ab}}$ - absolute temperature, (K).

\subsection{Thermodynamic drying properties}

The thermodynamic properties of the araticum epicarp drying were obtained by the method described by Jideani \& Mpotokwana (2009) (Equations. 21, 22 and 23):

$$
\begin{aligned}
& \Delta \mathrm{H}=\mathrm{E}_{\mathrm{a}}-\mathrm{R} \cdot \mathrm{T} \\
& \Delta \mathrm{S}=\mathrm{R} \cdot\left(\ln \mathrm{k}-\ln \frac{\mathrm{k}_{\mathrm{B}}}{\mathrm{h}_{\mathrm{p}}}\right)-\ln \mathrm{T}_{\mathrm{abs}} \\
& \Delta \mathrm{G}=\Delta \mathrm{H}-\mathrm{T}_{\mathrm{abs}} \cdot \Delta \mathrm{S}
\end{aligned}
$$

Where,

$\Delta \mathrm{H}$ - enthalpy $\left(\mathrm{J} \mathrm{mol}^{-1}\right)$;

$\Delta \mathrm{S}$ - entropy $\left(\mathrm{J} \mathrm{mol}^{-1}\right)$;

$\Delta \mathrm{G}$ - Gibbs free energy $\left(\mathrm{J} \mathrm{mol}^{-1}\right)$;

$\mathrm{k}_{\mathrm{B}}$ - Boltzmann constant $\left(1.38 \times 10^{-23} \mathrm{~J} \mathrm{~K}^{-1}\right)$; and

$h_{p}$ - Planck constant $\left(6.626 \times 10^{-34} \mathrm{~J} \mathrm{~s}^{-1}\right)$.

\section{Results and discussion}

It can be noted that the drying air temperature has an influence on the drying rate and the final drying time of the epicarp, because the higher the temperature, the shorter the time for drying the product. This behavior has been reported in studies by several researchers: horned melon peel (Barros et al., 2019), passion fruit peel (Bezerra et al., 2015) and mulungu peel (Martins et al., 2014). The drying times were $21,15,13$ and 11 hours for temperatures of $40,50,60$ and $70{ }^{\circ} \mathrm{C}$, respectively, until reaching the final moisture content of 0.05 (d.b.) (Figure 1).

It can be observed that all models, for all drying conditions, showed low values of the mean estimated error (SE), close to zero and representing satisfactory fit of the models (Table 2). The closer to zero the SE value, the greater the capacity to represent the physical process of drying (Draper \& Smith, 1998).

Regarding the mean relative error $(\mathrm{P})$, values lower than $10 \%$ were obtained for all drying temperatures only for the Midilli, Logarithmic and Two Terms models. According to Mohapatra \& Srinivasa Rao (2005), this is a condition that determines a satisfactory fit of the model to the drying conditions.

For all models, except Wang \& Singh, the determination coefficients $\left(\mathrm{R}^{2}\right)$ were greater than 0.9978 , which Madamba et al. (1996) considers a satisfactory representation of the drying 
process, and the closer to $100 \%$ the value of this parameter, the better the representation of the model. Table 2 also shows that all models had low values of Chi-square test $\left(\chi^{2}\right)$, and the lower this value, the better the fit of the model to the conditions.

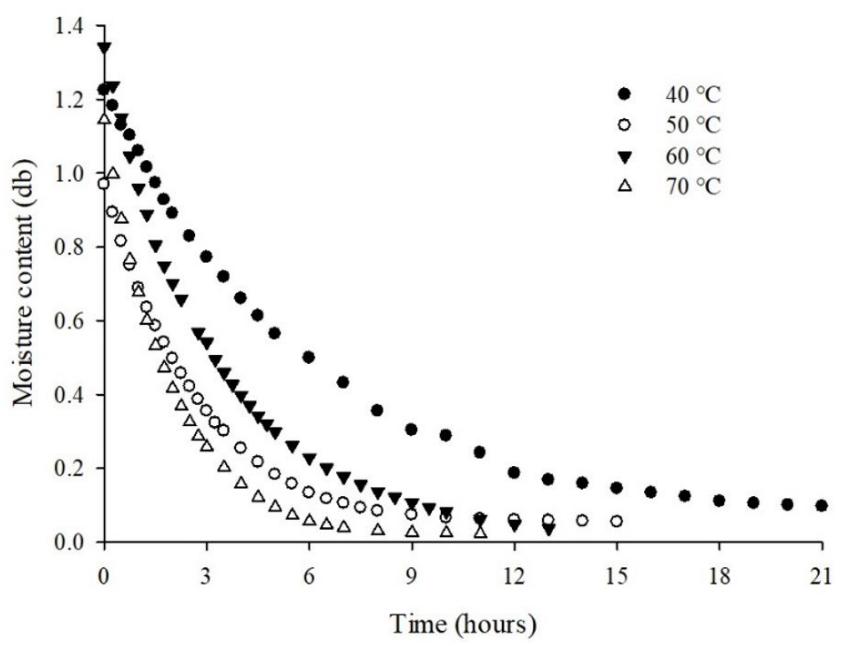

Figure 1. Moisture content of araticum epicarp during the drying at different temperatures.
Thus, it can be verified that the Midilli, Logarithmic and Two Terms models can be used to represent the drying of araticum epicarp. However, the Two Terms model was selected to represent the drying data of araticum epicarp as it had the lowest values, according to the AIC and BIC criteria (Table 3).

Recently, several researchers have updated, based on the AIC and BIC criteria to select with greater accuracy, the best mathematical model to represent the drying curves for different agricultural products (Gomes et al., 2018; Quequeto et al., 2019; Souza et al., 2019; Bastos et al., 2019; Pinheiro et al., 2020; Siqueira et al., 2020).

Figure $2 \mathrm{~A}$ shows the moisture content ratio obtained experimentally and estimated by the Two Terms model. Ferreira et al. (2020), working with drying of papaya (Carica papaya) cubes at different temperatures, selected the Two Terms model. Silva et al. (2018), working with 'Cabacinha' pepper seeds (Capsicum chinense L.), also found that the Two Terms model was the best to predict the drying curves.

Figure $2 \mathrm{~B}$ shows the values of the effective diffusion coefficient for the araticum epicarp during drying under different air conditions. The diffusion coefficient values obtained were $0.545 \times 10^{-9}, 1.201 \times 10^{-9}, 1.109 \times 10^{-9}$ and $1.839 \times 10^{-9} \mathrm{~m}^{2} \mathrm{~s}^{-1}$ for temperatures of $40,50,60$ and $70^{\circ} \mathrm{C}$, respectively. The values of

Table 2. Statistical parameters of the models for the drying of araticum epicarp.

\begin{tabular}{|c|c|c|c|c|c|c|c|c|}
\hline \multirow{2}{*}{ Models } & \multicolumn{4}{|c|}{$40^{\circ} \mathrm{C}$} & \multicolumn{4}{|c|}{$50^{\circ} \mathrm{C}$} \\
\hline & SE & $\mathrm{P}$ & $\mathrm{R}^{2}$ & $\chi^{2}$ & SE & $\mathrm{P}$ & $\mathrm{R}^{2}$ & $\chi^{2}$ \\
\hline Wang \& Sing & 0.0407 & 20.637 & 0.9851 & 0.001657 & 0.0885 & 68.810 & 0.9123 & 0.007839 \\
\hline Verma & 0.0092 & 5.732 & 0.9993 & 0.000086 & 0.0141 & 14.662 & 0.9978 & 0.000201 \\
\hline Thompson & 0.0086 & 4.730 & 0.9993 & 0.000074 & 0.0122 & 12.489 & 0.9983 & 0.000150 \\
\hline Page & 0.0090 & 5.411 & 0.9993 & 0.000081 & 0.0134 & 13.859 & 0.9980 & 0.000180 \\
\hline Newton & 0.0089 & 5.732 & 0.9993 & 0.000080 & 0.0137 & 14.662 & 0.9978 & 0.000188 \\
\hline Midilli & 0.0071 & 2.436 & 0.9993 & 0.000051 & 0.0035 & 2.044 & 0.9999 & 0.000013 \\
\hline Logarithmic & 0.0076 & 3.366 & 0.9995 & 0.000058 & 0.0069 & 5.653 & 0.9995 & 0.000048 \\
\hline Henderson \& Pabis & 0.0091 & 5.765 & 0.9995 & 0.000083 & 0.0069 & 14.562 & 0.9978 & 0.000048 \\
\hline Two-Term Exponential & 0.0085 & 4.633 & 0.9993 & 0.000073 & 0.0139 & 14.662 & 0.9978 & 0.000194 \\
\hline Two Terms & 0.0094 & 5.765 & 0.9996 & 0.000089 & 0.0043 & 3.402 & 0.9998 & 0.000019 \\
\hline $\begin{array}{c}\text { Approximation of } \\
\text { Diffusion }\end{array}$ & 0.0069 & 2.442 & 0.9996 & 0.000047 & 0.0076 & 14.662 & 0.9978 & 0.000058 \\
\hline \multirow{2}{*}{ Models } & \multicolumn{4}{|c|}{$60^{\circ} \mathrm{C}$} & \multicolumn{4}{|c|}{$70^{\circ} \mathrm{C}$} \\
\hline & $\mathrm{SE}$ & $\mathrm{P}$ & $\mathrm{R}^{2}$ & $x^{2}$ & SE & $\mathrm{P}$ & $\mathrm{R}^{2}$ & $\chi^{2}$ \\
\hline Wang \& Sing & 0.067134 & 55.919 & 0.9448 & 0.004507 & 0.1024 & 161.277 & 0.8838 & 0.010490 \\
\hline Verma & 0.011731 & 5.997 & 0.9984 & 0.000137 & 0.0060 & 9.454 & 0.9996 & 0.000037 \\
\hline Thompson & 0.005727 & 3.823 & 0.9996 & 0.000032 & 0.0049 & 8.565 & 0.9997 & 0.000024 \\
\hline Page & 0.005727 & 3.823 & 0.9996 & 0.000032 & 0.0042 & 8.942 & 0.9998 & 0.000018 \\
\hline Newton & 0.011359 & 5.996 & 0.9984 & 0.000129 & 0.0058 & 9.454 & 0.9996 & 0.000033 \\
\hline Midilli & 0.005142 & 1.441 & 0.9997 & 0.000026 & 0.0041 & 6.496 & 0.9998 & 0.000017 \\
\hline Logarithmic & 0.007956 & 5.119 & 0.9993 & 0.000063 & 0.0044 & 6.296 & 0.9998 & 0.000020 \\
\hline Henderson \& Pabis & 0.009616 & 4.263 & 0.9989 & 0.000092 & 0.0050 & 9.067 & 0.9997 & 0.000025 \\
\hline Two-Term Exponential & 0.005837 & 3.999 & 0.9996 & 0.000034 & 0.0041 & 8.913 & 0.9998 & 0.000017 \\
\hline Two Terms & 0.004541 & 1.673 & 0.9998 & 0.000020 & 0.0052 & 9.054 & 0.9997 & 0.000027 \\
\hline $\begin{array}{c}\text { Approximation of } \\
\text { Diffusion }\end{array}$ & 0.004638 & 1.710 & 0.9997 & 0.000021 & 0.0039 & 8.939 & 0.9998 & 0.000016 \\
\hline
\end{tabular}

SE - Mean estimated error (decimal); P - Mean relative error (\%); R2 - Coefficient of determination (decimal); $\chi 2$ - Chi-square (decimal). 
the effective diffusion coefficients are within the recommended range for food materials mentioned in the literature, which, according to Madamba et al. (1996), present in the order of $10^{-11}$ a $10^{-9} \mathrm{~m}^{2} \mathrm{~s}^{-1}$. It is verified that the effective diffusion coefficient of araticum epicarp increases with the increase in drying air temperature, corroborating the results obtained by Freitas et al. (2018), analyzing different temperatures in the drying of yellow mombin.

It is noted that the linear model satisfactorily represented the effective diffusion coefficient as a function of the drying temperature, with a high coefficient of determination (0.8427). Diffusivity depends on the drying air temperature, i.e. the higher the drying air temperature, the lower the resistance of the epicarp to water removal, and the greater the diffusivity (Muliterno et al., 2017).

The activation energy for the epicarp drying process was $32.045 \mathrm{~kJ} \mathrm{~mol}^{-1}$ for the temperature range studied. In drying processes, the lower the activation energy, the greater the diffusivity of water in the product. Activation energy is a barrier that must be overcome so that the diffusion process can be triggered in the product (Kashaninejad et al., 2007).

The literature reports values of activation energy for various agricultural products: $21.50 \mathrm{~kJ} \mathrm{~mol}^{-1}$ for yellow mombin epicarp (Pinheiro et al., 2020), $29.18 \mathrm{~kJ} \mathrm{~mol}^{-1}$ for biofortified sweet potato (Souza et al., 2019) and $34.72 \mathrm{~kJ} \mathrm{~mol}^{-1}$ for passion fruit peel (Bezerra et al., 2015). According to Zogzas et al. (1996), the activation energy for agricultural products ranges from 12.7 to $110 \mathrm{~kJ} \mathrm{~mol}^{-1}$. Thus, the value obtained in the present study is within this range.

In the evaluation of enthalpy, entropy and Gibbs free energy, both enthalpy and entropy tend to decrease when temperature increases (Table 4). According to Oliveira et al. (2010), lower enthalpy values indicate lower energy needed to remove the water bound to the product during drying. The present study

Table 3. Akaike Information Criterion (AIC) and Schwarz's Bayesian Information Criterion (BIC) for the models that fitted best to the drying data of araticum epicarp and the parameters of the selected model.

\begin{tabular}{|c|c|c|c|c|c|c|c|c|}
\hline \multirow{3}{*}{ Model } & \multicolumn{8}{|c|}{ Temperature $\left({ }^{\circ} \mathrm{C}\right)$} \\
\hline & \multicolumn{2}{|c|}{40} & \multicolumn{2}{|c|}{50} & \multicolumn{2}{|c|}{60} & \multicolumn{2}{|c|}{70} \\
\hline & AIC & $\mathrm{BIC}$ & AIC & $\mathrm{BIC}$ & AIC & $\mathrm{BIC}$ & AIC & $\mathrm{BIC}$ \\
\hline Midilli & -212.65 & -205.48 & -243.76 & -236.59 & -248.38 & -240.90 & -197.45 & -191.36 \\
\hline Logarithmic & -209.09 & -203.35 & -215.18 & -209.45 & -220.48 & -214.49 & -194.42 & -189.55 \\
\hline \multirow[t]{3}{*}{ Two Terms } & -215.44 & -208.27 & -255.14 & -247.97 & -256.57 & -249.09 & -197.54 & -191.44 \\
\hline & \multicolumn{8}{|c|}{ Coefficients } \\
\hline & \multicolumn{2}{|c|}{40} & \multicolumn{2}{|c|}{50} & \multicolumn{2}{|c|}{60} & \multicolumn{2}{|c|}{70} \\
\hline \multirow[t]{3}{*}{ Two Terms } & \multicolumn{2}{|c|}{$\mathrm{a}=1.004^{\star *}$} & \multicolumn{2}{|c|}{$\mathrm{a}=0.003157^{\mathrm{ns}}$} & \multicolumn{2}{|c|}{$\mathrm{a}=0.123555^{\star *}$} & \multicolumn{2}{|c|}{$a=0.9905^{\star *}$} \\
\hline & \multirow{2}{*}{\multicolumn{2}{|c|}{$\begin{aligned} \mathrm{k}_{0} & =0.1605^{\star *} \\
\mathrm{~b} & =0.00007494^{\mathrm{ns}}\end{aligned}$}} & \multicolumn{2}{|c|}{$\begin{aligned} \mathrm{k}_{0} & =-0.171238^{* *} \\
\mathrm{~b} & =1.000248^{* *}\end{aligned}$} & \multicolumn{2}{|c|}{$\begin{aligned} \mathrm{k}_{0} & =0.951970^{\star *} \\
\mathrm{~b} & =0.882115^{\star *}\end{aligned}$} & \multicolumn{2}{|c|}{$\begin{aligned} \mathrm{k}_{0} & =0.5090^{\star *} \\
\mathrm{~b} & =0.00006043^{\mathrm{ns}}\end{aligned}$} \\
\hline & $\mathrm{k}_{1}=-0.2744^{\star}$ & & \multicolumn{2}{|c|}{$\mathrm{k}_{1}=0.351745^{\star \star}$} & \multicolumn{2}{|c|}{$\mathrm{k}_{1}=0.280512 * *$} & \multicolumn{2}{|c|}{$\mathrm{k}_{1}=-0.4769^{\mathrm{ns}}$} \\
\hline
\end{tabular}

** Significant at $\mathrm{p} \leq 0.01$ by $\mathrm{t}$-test; ${ }^{*}$ Significant at $\mathrm{p} \leq 0.05$ by t-test. $\mathrm{ns}-$ Not significant by $\mathrm{t}$-test.

A.



B.

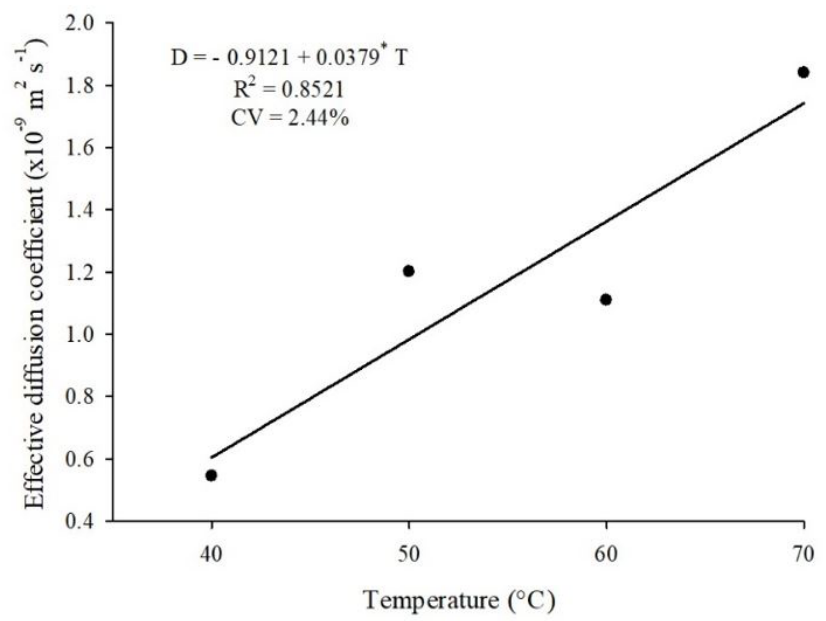

Figure 2. Moisture content ratio obtained experimentally and estimated by the Two Terms model (A) and effective diffusion coefficient for the different temperatures in the drying of araticum epicarp. ${ }^{*}$ - Significant at $\mathrm{p} \leq 0.05$ by the F test. 
Table 4. Values of enthalpy $\left(\Delta \mathrm{H}, \mathrm{kJ} \mathrm{mol}^{-1}\right)$, entropy $\left(\Delta \mathrm{S}, \mathrm{kJ} \mathrm{mol}^{-1} \mathrm{~K}^{-1}\right)$ and Gibbs free energy $\left(\Delta \mathrm{G}, \mathrm{kJ} \mathrm{mol}^{-1}\right)$ for different drying air conditions of araticum epicarp.

\begin{tabular}{cccc}
\hline \multirow{2}{*}{ Temperature } & \multicolumn{3}{c}{ Thermodynamic properties } \\
\cline { 2 - 4 } & $\Delta \mathrm{H}$ & $\Delta \mathrm{S}$ & $\Delta \mathrm{G}$ \\
\hline 40 & 29.26105 & -0.17139 & 82.93150 \\
50 & 29.17213 & -0.17165 & 84.64092 \\
60 & 29.08321 & -0.17190 & 86.35292 \\
70 & 28.99429 & -0.17215 & 88.06742 \\
\hline
\end{tabular}

reported lower enthalpy values for higher drying temperatures, which indicates that less energy is required for drying to occur at higher temperatures.

According to Goneli et al. (2010), entropy is a thermodynamic property associated with the degree of disorder, being a state function, and its values increase during a natural process in an isolated system. The fact that entropy values decrease dramatically when temperature increases is due to the greater excitation of water molecules within the product. The negative values of entropy were attributed to the existence of chemical adsorption and/or structural changes of the adsorbent (Moreira et al., 2008).

Nkolo Meze'e et al. (2008) report that Gibbs free energy is attributed to the work required to make sorption sites available. With the increase in temperature, Gibbs free energy increased and its values were positive, so this indicates that the drying under the conditions of the present study was not spontaneous.

The study of thermodynamic properties is of great importance for the dimensioning of equipment drying, as they involve the calculation of energy necessary for the process to take place and evaluate physical phenomena that occur on the surface of products (Oliveira et al., 2014). Several studies regarding the thermodynamic properties of agricultural products have been researched and corroborate the results of this work: beet root (Iglesias et al., 1976); coffee fruits (Corrêa et al., 2010); corn ears (Corrêa et al., 2011); bode pepper (Rodovalho et al., 2015); jabuticaba peel (Costa et al., 2016); peanut kernels (Goneli et al., 2017); okara (Guimarães et al., 2018); corn and soy (Granella et al., 2019); mulatto beans (Lisboa et al., 2019); Piper aduncum L. leaves (Quequeto et al., 2019).

\section{Conclusion}

Araticum epicarp drying time decreases with increasing temperature.

Two Terms is the indicated model, as it had better fit to the experimental drying data of araticum epicarp under the different drying conditions.

The linear model satisfactorily represented the effective diffusion coefficient as a function of drying temperature.

In the evaluation of enthalpy, entropy and Gibbs free energy, both enthalpy and entropy tend to decrease when temperature increases.

The higher the temperature used in the drying of araticum epicarp, the lower the diffusivity value, i.e., the lower the resistance to water removal. Also, the low activation energy points to a certain ease of water migration to the outside of the product.

\section{Acknowledgements}

The authors thank IF Goiano, CAPES, FAPEG, FINEP and $\mathrm{CNPq}$ for the indispensable financial support to conduct this study.

\section{References}

Association of Official Analytical Chemists - AOAC. (2012). Official methods of analysis of the Association of Official Analytical Chemists (19. ed., p. 771). Washington: AOAC.

Aprajeeta, J., Gopirajah, R., \& Anandharamakrishnan, C. (2015). Shrinkage and porosity effects on heat and mass transfer during potato drying. Journal of Food Engineering, 144, 119-128. http:// dx.doi.org/10.1016/j.jfoodeng.2014.08.004.

Barros, S. L., Câmara, G. B., Farias Leite, D. D., Santos, N. C., Santos, F. S., Cunha Soares, T., Lima, A. R. N., Soares, T. C., Oliveira, M. N., Vasconcelos, U. A. A., Albuquerque, A. P., \& Queiroz, A. J. M. (2019). Modelagem matemática da cinética de secagem de cascas do kino (Cucumis metuliferus). Research. Social Development, 9, 1-18.

Bastos, A. V. S., Amaral, A. M., Gomes, F. H. F., Xavier, W., \& Resende, O. (2019). Drying kinetics of Cecropia pachystachya leaves. Floresta e Ambiente, 26(3), 1-9. http://dx.doi.org/10.1590/2179-8087.042218.

Bezerra, C. V. B., Silva, L. H. M., Corrêa, D. F., \& Rodrigues, A. M. C. (2015). A modeling study for moisture diffusivities and moisture transfer coefficients in drying of passion fruit peel. International Journal of Heat and Mass Transfer, 85, 750-755. http://dx.doi. org/10.1016/j.ijheatmasstransfer.2015.02.027.

Costa, L. M., Resende, O., Goncalves, D. N., \& Oliveira, D. E. C. (2015). Modelagem matemática da secagem de frutos de crambe em camada delgada. Bioscience Journal, 31(2), 392-403. http://dx.doi. org/10.14393/BJ-v31n2a2015-22340.

Costa, C. F., Corrêa, P. C., Vanegas, J. D., Baptestini, F. M., Campos, R. C., \& Fernandes, L. S. (2016). Mathematical modeling and determination of thermodynamic properties of jabuticaba peel during the drying process. Revista Brasileira de Engenharia Agrícola e Ambiental, 20(6), 576-580. http://dx.doi.org/10.1590/1807-1929/ agriambi.v20n6p576-580.

Corrêa, P. C., Botelho, F. M., Oliveira, G. H. H., Goneli, A. L. D., Resende, O., \& Campos, S. D. C. (2011). Mathematical modeling of the drying process of corn ears. Acta Scientiarum. Agronomy, 33(4), 575-581. http://dx.doi.org/10.4025/actasciagron.v33i4.7079.

Corrêa, P. C., Oliveira, G. H. H., Botelho, F. M., Goneli, A. L. D., \& Carvalho, F. M. (2010). Modelagem matemática e determinação das propriedades termodinâmicas do café (Coffea arabica L.) durante o processo de secagem. Revista Ceres, 57(5), 595-601. http://dx.doi. org/10.1590/S0034-737X2010000500005.

Draper, N. R., \& Smith, H. (1998). Applied regression analysis (3. ed., p. 712). New York: John Wiley \& Sons. http://dx.doi. org/10.1002/9781118625590.

Fachinello, J. C., \& Nachtigal, J. C. (2010). Situação da fruticultura no Brasil. In: Introdução a Fruticultura. Embrapa.

Freitas, B. S. M., Cavalcante, M. D., Cagnin, C., Silva, R. M., Placido, G. R., \& Oliveira, D. E. C. (2018). Physical-chemical characterization of yellow mombin (Spondias mombin L.) foam-mat drying at different temperatures. Revista Brasileira de Engenharia Agrícola e Ambiental, 22(6), 430-435. http://dx.doi.org/10.1590/1807-1929/ agriambi.v22n6p430-435. 
Ferreira, J. P. D. L., Castro, D. S. D., Moreira, I. D. S., Silva, W. P. D., Figueirêdo, R. M., \& Queiroz, A. J. D. M. (2020). Convective drying kinetics of osmotically pretreated papaya cubes. Revista Brasileira de Engenharia Agrícola e Ambiental, 24(3), 200-208. http://dx.doi. org/10.1590/1807-1929/agriambi.v24n3p200-208.

Gomes, F. P., Osvaldo, R., Sousa, E. P., de Oliveira, D. E. C., \& Araújo, F. R. D. No. (2018). Drying kinetics of crushed mass of 'jambu': Effective diffusivity and activation energy. Revista Brasileira de Engenharia Agrícola e Ambiental, 22(7), 499-505. http://dx.doi. org/10.1590/1807-1929/agriambi.v22n7p499-505.

Goneli, A. L. D., Corrêa, P. C., Oliveira, G. D., \& Botelho, F. M. (2010). Water desorption and thermodynamic properties of okra seeds. Transactions of the ASABE, 53(1), 191-197. http://dx.doi. org/10.13031/2013.29486.

Goneli, A. L., Araujo, W. D., Hartmann, C. P. Fo., Martins, E. A., \& Oba, G. C. (2017). Drying kinetics of peanut kernels in thin layers. Engenharia Agrícola, 37(5), 994-1003. http://dx.doi.org/10.1590/18094430-eng.agric.v37n5p994-1003/2017.

Granella, S. J., Bechlin, T. R., Christ, D., Zanardi, B., Rego, J. M., \& Coelho, S. R. M. (2019). Improvement of heat \& mass transfer with added ozone into drying air on corn-soy. Engineering in Agriculture, Environment and Food, 12(4), 427-434. http://dx.doi.org/10.1016/j. eaef.2019.07.001.

Guimarães, R. M., Oliveira, D. E., Resende, O., Silva, J. D. S., de Rezende, T. A., \& Egea, M. B. (2018). Thermodynamic properties and drying kinetics of 'okara'. Revista Brasileira de Engenharia Agrícola e Ambiental, 22(6), 418-423. http://dx.doi.org/10.1590/1807-1929/ agriambi.v22n6p418-423.

Iglesias, H. A., Chirife, J., \& Viollaz, P. (1976). Thermodynamics of water vapour sorption by sugar beet root. International Journal of Food Science \& Technology, 11(1), 91-101. http://dx.doi. org/10.1111/j.1365-2621.1976.tb00705.x.

Jideani, V. A., \& Mpotokwana, S. M. (2009). Modeling of water absorption of botswana bambara varieties using Peleg's equation. Journal of Food Engineering, 92(2), 182-188. http://dx.doi.org/10.1016/j. jfoodeng.2008.10.040.

Kashaninejad, M., Mortazavi, A., Safekordi, A., \& Tabil, L. G. (2007). Thin-layer drying characteristics and modeling of pistachio nuts. Journal of Food Engineering, 78(1), 98-108. http://dx.doi.org/10.1016/j. jfoodeng.2005.09.007.

Lisboa, H. M., Araujo, H., Paiva, G., Oriente, S., Pasquali, M., Duarte, M. E., \& Mata, M. E. C. (2019). Determination of characteristic properties of mulatto beans (Phaseolus vulgaris L.) during convective drying. Journal of Agriculture and Food Research, 1, 100003. http:// dx.doi.org/10.1016/j.jafr.2019.100003.

Martins, J. J. A., Marques, J. I., da Costa Santos, D., \& Rocha, A. P. T. (2014). Modelagem matemática da secagem de cascas de mulungu. Bioscience Journal, 30, 1652-1660.

Machado, A. R. M. C. (2011). Obtenção de produtos a partir das folhas de Copaifera langsdorffii Desf:: otimização da extração e secagem em spray dryer utilizando planejamentos experimentais (Tese de doutorado). Universidade de São Paulo, Ribeirão Preto.

Madamba, P. S., Driscoll, R. H., \& Buckle, K. A. (1996). Thin-layer drying characteristics of garlic slices. Journal of Food Engineering, 29(1), 75-97. http://dx.doi.org/10.1016/0260-8774(95)00062-3.

Mohapatra, D., \& Srinivasa Rao, P. (2005). A thin layer drying model of parboiled wheat. Journal of Food Engineering, 66(4), 513-518. http://dx.doi.org/10.1016/j.jfoodeng.2004.04.023.
Moreira, R., Chenlo, F., Torres, M. D., \& Vallejo, N. (2008). Thermodynamic analysis of experimental sorption isotherms of loquat and quince fruits. Journal of Food Engineering, 88(4), 514-521. http://dx.doi. org/10.1016/j.jfoodeng.2008.03.011.

Muliterno, M. M., Rodrigues, D., de Lima, F. S., Ida, E. I., \& Kurozawa, L. E. (2017). Conversion/degradation of isoflavones and color alterations during the drying of okara. Lebensmittel-Wissenschaft + Technologie, 75, 512-519. http://dx.doi.org/10.1016/j.lwt.2016.09.031.

Nkolo Meze'e, Y. N., Noah Ngamveng, J., \& Bardet, S. (2008). Effect of enthalpy-entropy compensation during sorption of water vapour in tropical woods: the case of Bubinga (Guibourtia Tessmanii J. Leonard, G. Pellegriniana J. L.). Thermochimica Acta, 468(1-2), 1-5. http://dx.doi.org/10.1016/j.tca.2007.11.002.

Oliveira, G. H. H., Corrêa, P. C., Araújo, E. F., Valente, D. S. M., \& Botelho, F. M. (2010). Desorption isotherms and thermodynamic properties of sweet corn cultivars (Zea mays L.). International Journal of Food Science \& Technology, 45(3), 546-554. http://dx.doi. org/10.1111/j.1365-2621.2009.02163.x.

Oliveira, D. E. C., Resende, O., Chaves, T. H., Souza, K. A., \& Smaniotto, T. A. S. (2014). Propriedades termodinâmicas das sementes de pinhão-manso. Bioscience Journal, 30, 147-157.

Pinheiro, G. K., Oliveira, D. E. C., Ferreira, W. N. Jr, \& Resende, O. (2020). Drying kinetics of yellow mombin (Spondias mombin L.) epicarp. Revista Brasileira de Engenharia Agrícola e Ambiental, 24(2), 121-127. http://dx.doi.org/10.1590/1807-1929/agriambi. v24n2p121-127.

Quequeto, W. D., Siqueira, V. C., Mabasso, G. A., Isquierdo, E. P., Leite, R. A., Ferraz, L. R., Hoscher, R. H., Schoeninger, V., Jordan, R. A., Goneli, A. L. D., \& Martins, E. A. S. (2019). Mathematical modeling of thin-layer drying kinetics of Piper aduncum L. leaves. The Journal of Agricultural Science, 11(8), 225-235. http://dx.doi. org/10.5539/jas.v11n8p225.

Rodovalho, R. S., da Silva, H. W., Silva, I. L., \& Rossetto, C. A. V. (2015). Cinética de secagem dos grãos de pimenta bode. Global Science and Technology, 8(2), 128-142. http://dx.doi.org/10.14688/1984-3801/ gst.v8n2p128-142.

Silva, H. W. D., Vale, L. S. Jr, Silva, C. F., Souza, R. D. C., \& Soares, R. S. (2018). Drying kinetics and physiological quality of 'Cabacinha' pepper seeds during storage. Revista Brasileira de Engenharia Agrícola e Ambiental, 22(4), 292-297. http://dx.doi.org/10.1590/1807-1929/ agriambi.v22n4p292-297.

Siqueira, V. C., Leite, R. A., Mabasso, G. A., Martins, E. A. S., Quequeto, W. D., \& Isquierdo, E. P. (2020). Drying kinetics and effective diffusion of buckwheat grains. Ciência e Agrotecnologia, 44, e011320. http:// dx.doi.org/10.1590/1413-7054202044011320.

Souza, D. G., Resende, O., Moura, L. C. D., Ferreira, W. N. Jr, \& Andrade, J. W. D. S. (2019). Drying kinetics of the sliced pulp of biofortified sweet potato (Ipomoea batatas L.). Engenharia Agrícola, 39(2), 176-181. http://dx.doi.org/10.1590/1809-4430-eng.agric. v39n2p176-181/2019.

Zogzas, N. P., Maroulis, Z. B., \& Marinos-Kouris, D. (1996). Moisture diffusivity data compilation in foodstuffs. Drying Technology, 14(10), 2225-2253. http://dx.doi.org/10.1080/07373939608917205.

Wolfinger, R. D. (1993). Covariance structure selection in general mixed models. Communications in Statistics, 22(4), 1079-1106. http://dx.doi.org/10.1080/03610919308813143. 